\title{
Four New Steroid Constituents from the Waste Residue of Fibre Separation from Agave americana Leaves
}

\author{
Jian-Ming JIN, Ying-Jun ZHANG, ${ }^{*}$ and Chong-Ren YANG \\ State Key Laboratory of Phytochemistry and Plant Resources in West China, Kunming Institute of Botany, Chinese \\ Academy of Sciences; Kunming 650204, People's Republic of China. \\ Received November 13, 2003; accepted March 4, 2004
}

Three new steroidal saponins, named agamenosides $\mathrm{H}-\mathbf{J}(1-3)$, and a new cholestane steroid agavegenin D (4) were isolated from the waste residue of fibre separation from Agave americana leaves, together with six known steroids. Structures of the new compounds $1-4$ were deduced to be $(22 S, 23 S, 24 R, 25 S)-24-[(\beta$-D-glucopyranosyl)oxy]-5 $\alpha$-spirostane-3 $\beta, 6 \alpha, 23$-triol 6- $O$ - $\beta$-D-glucopyranoside (1), (22S,23S,24R,25S)-5 $\alpha$-spirostane-3 $\beta, 23,24$ triol 24-O- $\beta$-D-glucopyranoside (2), (22S,23S,25R,26S)-23,26-epoxy-5 $\alpha$-furostane-3 $\beta, 22,26$-triol $26-O$ - $\beta$-D-glucopyranoside (3), and (22S,25S)-5 $\alpha$-cholestane-3 $\beta, 16 \beta, 22,26$-tetrol (4), respectively, by means of spectroscopic analysis, including extensive 1D and 2D NMR data, and the results of hydrolytic cleavage.

Key words Agave americana; Agavaceae; steroid; agamenoside H; agamenoside I; agamenoside J

The genus Agave belongs to the Agavaceae family with more than 300 species and occurs natively in arid and tropical regions of western hemisphere, particularly Mexico, and Central America. Among which, several species are of global economic importance, e.g., Agave sisalana, the source of sisal fibre, and other species, such as A. americana, growing world-wide as ornamentals. In China, several species of the genus Agave, such as A. americana and A. sisalana, are widely cultivated in the south part for the fibre industry and as important horticultural plants.

Agave americana L., a very large plant with rosettes up to 12 feet broad, is used as an important source for not only textile fibre, but also steroidal sapogenins such as hecogenin and tigogenin in China. ${ }^{1,2)}$ The plant is also used as folk medicine for its antiinflammatory and anti-fungus effects on the treatment of uterus blooding, scabies, etc. ${ }^{3}$ Since the chemical investigation on the fermented residues of the leaf-juice of $A$. sisalana led to the identification of some tigogenin glycosides, ${ }^{4,5}$ a lot of steroidal sapogenins and saponins were found from the fresh leaves and the fermented leaves of $A$. americana. ${ }^{6-14)}$ In a continuation of search for the bioactive saponins produced by agavaceous plants, and to utilize properly the fermented waste residue of $A$. americana, we have further studied the steroids constituents in the waste residue of fibre separation from A. americana leaves. As the result, three new steroid saponins, agamenosides $\mathrm{H}-\mathrm{J}(\mathbf{1}-\mathbf{3})$, and a new cholestane steroid agavegenin D (4), were isolated, together with six known steroids. This paper deals with a full account of the isolation and structural elucidation of these compounds.

\section{Results and Discussion}

The $\mathrm{MeOH}$ extract of the waste residue of fibre separation from $A$. american leaves was partitioned by $n-\mathrm{BuOH}$ and water. The $n$-BuOH layer was chromatographed successively over silica gel and RP-8 to afford compounds $\mathbf{1}-\mathbf{4}$ and six known steroids, identified as (25R)-5 $\alpha$-spirostane- $3 \beta, 6 \alpha$-diol (chlorogenin), ${ }^{15)}$ chlorogenin $\quad 6-O-\beta$-D-glucopyranoside, $\left.{ }^{15}\right)$ $9(11)$-dehydroxyhecogenin, ${ }^{16)}$ manogenin, ${ }^{16)}$ daucosterol $^{17}{ }^{17}$ and $7 \alpha$-hydroxysitosterol $3-O-\beta$-D-glucopyranoside, ${ }^{18)}$ respectively.

Compound 1 was obtained as a white amorphous powder. Its molecular formula was assigned as $\mathrm{C}_{39} \mathrm{H}_{64} \mathrm{O}_{16}$ on the basis of the ${ }^{13} \mathrm{C}$-NMR data and high resolution (HR)-FAB-MS $\left([\mathrm{M}-\mathrm{H}]^{-}, m / z\right.$ 787.4177). The ${ }^{1} \mathrm{H}-\mathrm{NMR}$ spectrum of $\mathbf{1}$ showed two three-proton singlet signals at $\delta 0.93$ and 0.76 and two three-proton doublet signals at $\delta 1.12(J=7.0 \mathrm{~Hz})$ and $1.20(J=6.4 \mathrm{~Hz})$, characteristic of the spirostanol skeleton, as well as signals for two anomeric protons at $\delta 4.91(\mathrm{~d}$, $J=7.8 \mathrm{~Hz})$ and $4.94(\mathrm{~d}, J=7.9 \mathrm{~Hz})$. Acid hydrolysis of 1 with $1 \mathrm{M} \mathrm{HCl}$ produced a new steroidal sapogenin 1a, and D-glucose as sugar residue determined by GC analysis. The $J$ val-
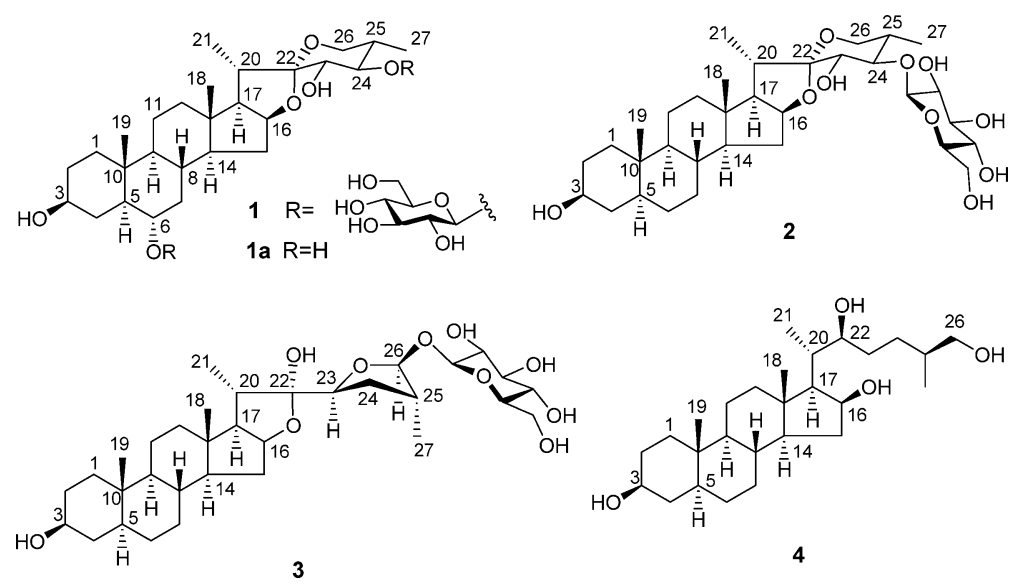
ues $(>7 \mathrm{~Hz})$ of two anomer proton signals indicated the $\beta$ orientation at the anomeric center of the D-glucopyranoses.

Aglycone 1a was a white powder, and exhibited four characteristic methyl signals at $\delta 1.06$ (s), 0.79 (s), 1.19 (d, $J=$ $6.5 \mathrm{~Hz}$ ) and $1.08(\mathrm{~d}, J=6.7 \mathrm{~Hz})$ in the ${ }^{1} \mathrm{H}-\mathrm{NMR}$ spectrum. Comparing the ${ }^{13} \mathrm{C}$-NMR data of $1 \mathrm{a}$ with those of hongguanggenin $^{19)}$ indicated that their signals from rings $\mathrm{A}-\mathrm{E}$ were identical with each other. Significant differences were observed for the chemical shifts of F-ring $\left(\delta_{\mathrm{C}} 113.4,73.8\right.$, $76.1,39.3,64.6,13.8)$, indicating that 1 a had two hydroxyl groups attached at F-ring of the spirostanol skeleton, in addition to two hydroxyl groups at attached at C-3 and C-6. Analysis of the ${ }^{1} \mathrm{H}-{ }^{1} \mathrm{H}$ homonuclear correlated spectroscopy (COSY) spectrum followed by the ${ }^{1} \mathrm{H}$-detected heteronuclear multiple quantum coherence (HMQC) spectrum identified all the proton and carbon signals arising from the F-ring part and gave unequivocal evidence that the loci of the two hydroxyl groups were at $\mathrm{C}-23$ and $\mathrm{C}-24$ positions. In the ${ }^{1} \mathrm{H}-\mathrm{de}-$ tected heteronuclear multiple bond correlation (HMBC) spectrum of 1a (Fig. 1), correlations of $\delta 1.08$ (H3-27) with $\delta 39.3(\mathrm{C}-25), 64.6(\mathrm{C}-26)$ and $76.1(\mathrm{C}-24)$, and $\delta 3.98(\mathrm{H}-$ 24) with $\delta 13.8(\mathrm{C}-27)$ and $73.8(\mathrm{C}-23)$ were also observed and confirmed the loci of the two hydroxyl groups at $\mathrm{C}-23$ and $\mathrm{C}-24$. In addition, HMBC correlation of $\delta 3.66(\mathrm{H}-26)$ with $\delta 113.4$ (C-22) revealed the connection of F-ring part with the E-ring part through the $\mathrm{C}-22$ acetal carbon. The ${ }^{1} \mathrm{H}-$ and ${ }^{13} \mathrm{C}$-NMR data for the F-ring of 1 a was identical with those of trillenogenin, ${ }^{20)}$ which was isolated from Trillium kamtschaticum, indicating that 1a had the same $22 S$ and $25 S$ configurations as those of trillenogenin. The $25 \mathrm{~S}$ configuration of 1a was also supported by of the IR spectrum evidence (band at $895 \mathrm{~cm}^{-1}$ stronger than the band at $868 \mathrm{~cm}^{-1}$ ), ${ }^{21)}$ and by comparing the NMR data with those of hongguanggenin. The proton coupling constants of H-23 [ $\delta 3.88$ (d, $J=$ $8.7 \mathrm{~Hz})]$ and $\mathrm{H}-24[\delta 3.98(\mathrm{dd}, J=9.5,8.7 \mathrm{~Hz})]$ suggested $\alpha$ orientation of $\mathrm{C}-23$ hydroxyl group and $\beta$-orientation for $\mathrm{C}$ 24 hydroxyl group. In the rotational nuclear Overhauser effect spectroscopy (ROESY) spectrum of 1a, correlations of $\delta$ $3.88(\mathrm{H}-23)$ with $\delta 1.19(\mathrm{H}-21), 2.06(\mathrm{H}-25)$, and $3.08(\mathrm{H}-$ $20)$, of $\delta 3.92(\mathrm{H}-3)$ with $\delta 1.02(\mathrm{H}-1 \alpha), 1.34(\mathrm{H}-5), 2.06$ $(\mathrm{H}-2 \alpha)$, and $3.01(\mathrm{H}-4 \alpha)$, of $\delta 3.59(\mathrm{H}-6)$ with $\delta 3.98(\mathrm{H}-$ 19), $1.61(\mathrm{H}-8)$ and $2.21(\mathrm{H}-7 \beta)$, and of $\delta 3.98(\mathrm{H}-24)$ with $\delta$ $1.08(\mathrm{H}-27)$ and $3.66(\mathrm{H}-26)$ were observed and confirmed the $3 \beta, 6 \alpha, 22 S, 23 S, 24 R$ and $25 S$ configurations. On the basis of the above evidences, 1a was deduced to be (22S,23S,24R,25S)-5 $\alpha$-spirostane-3 $\beta, 6 \alpha, 23,24$-tetrol, and named agavegenin $C$.

The combination analysis of $1 \mathrm{D}$ and 2D NMR assigned the proton and carbon signals of 1 (Table 1). Locations of the sugar moieties on C-6 and C-24 of the aglycone (1a) were revealed by the HMBC correlations of $\delta 79.6$ (C-6) with one anomeric proton signal at $\delta 4.91\left(\mathrm{H}-1^{\prime}\right)$ and of $\delta 87.7(\mathrm{C}-24)$ with another anomeric proton signal at $\delta 4.94$ (H-1"). Therefore, the structure of $\mathbf{1}$ was elucidated to be $(22 S, 23 S, 24 R$, $25 S)$-24-[( $\beta$-D-glucopyranosyl)oxy $]-5 \alpha$-spirostane-3 $\beta, 6 \alpha, 23$ triol $6-O-\beta$-D-glucopyranoside and designated as agamenoside $\mathrm{H}$.

Compound 2 was shown to have the molecular formula $\mathrm{C}_{33} \mathrm{H}_{54} \mathrm{O}_{10}$ on the basis of HR-FAB-MS ( $\mathrm{m} / \mathrm{z} 609.3676$ $[\mathrm{M}-\mathrm{H}]^{-}$) and ${ }^{13} \mathrm{C}$ distortionless enhancement by polarization transfer (DEPT) spectrum. The ${ }^{1} \mathrm{H}-\mathrm{NMR}$ spectrum of $\mathbf{2}$

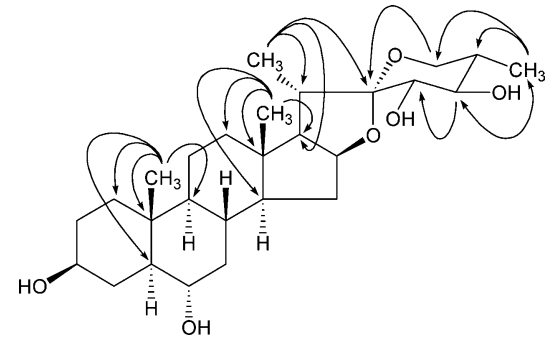

Fig. 1. Important HMBC Correlations of 1a

Table 1. ${ }^{1} \mathrm{H}-$ and ${ }^{13} \mathrm{C}-\mathrm{NMR}$ Data of Compounds $\mathbf{1}$ and $\mathbf{1 a}$

\begin{tabular}{|c|c|c|c|}
\hline \multirow{2}{*}{ No. } & \multicolumn{2}{|r|}{1} & 1a \\
\hline & $\delta_{\mathrm{C}}$ & $\delta_{\mathrm{H}}$ & $\delta_{\mathrm{H}}$ \\
\hline 1 & $37.9(\mathrm{t})$ & $0.92(\alpha), 1.58(\beta)$ & $38.0(\mathrm{t}) \quad 1.02(\alpha), 1.64(\beta)$ \\
\hline 2 & $32.3(\mathrm{t})$ & $2.02(\alpha), 1.48(\beta)$ & $32.4(\mathrm{t}) 2.06(\alpha), 1.56(\beta)$ \\
\hline 3 & $70.8(d)$ & 3.74 & $71.1(d) 3.92$ \\
\hline 4 & $33.2(\mathrm{t})$ & $3.22(\alpha), 1.62(\beta)$ & $33.7(\mathrm{t}) 3.01(\alpha), 1.67(\beta)$ \\
\hline 5 & $51.4(d)$ & 1.35 & $52.8(\mathrm{~d}) 1.34$ \\
\hline 6 & $79.6(d)$ & 3.67 & $68.7(d) 3.59$ \\
\hline 7 & $41.4(\mathrm{t})$ & $1.18(\alpha), 2.56(\beta)$ & $42.8(\mathrm{t}) \quad 1.24(\alpha), 2.21(\beta)$ \\
\hline 8 & $34.1(\mathrm{~d})$ & 1.56 & 34.3 (d) 1.61 \\
\hline 9 & $54.1(\mathrm{~d})$ & 0.58 & 54.3 (d) 0.69 \\
\hline 10 & $36.8(\mathrm{~s})$ & & $36.6(s)$ \\
\hline 11 & $21.4(t)$ & $1.18(\alpha), 1.41(\beta)$ & $21.4(\mathrm{t}) \quad 1.45(\alpha), 1.48(\beta)$ \\
\hline 12 & $40.5(\mathrm{t})$ & $1.15(\alpha), 1.70(\beta)$ & $40.6(\mathrm{t}) \quad 1.15(\alpha), 1.74(\beta)$ \\
\hline 13 & $41.4(\mathrm{~s})$ & & $41.4(\mathrm{~s})$ \\
\hline 14 & $56.6(d)$ & 1.04 & $56.5(\mathrm{~d}) 1.22$ \\
\hline 15 & $32.1(\mathrm{t})$ & $1.97(\alpha), 1.70(\beta)$ & $32.2(\mathrm{t}) 2.09(\alpha), 1.70(\beta)$ \\
\hline 16 & 81.9 (d) & 4.49 (q-like, 7.5$)$ & 82.1 (d) 4.66 (q-like, 8.0) \\
\hline 17 & $62.0(\mathrm{~d})$ & $1.78(\mathrm{dd}, 6.8,7.5)$ & 62.1 (d) $1.90(\mathrm{dd}, 7.6,8.0)$ \\
\hline 18 & $17.0(q)$ & $0.93(\mathrm{~s})$ & $17.0(q) 1.06(s)$ \\
\hline 19 & $13.6(q)$ & $0.76(\mathrm{~s})$ & $13.7(q) 0.79(\mathrm{~s})$ \\
\hline 20 & $36.5(d)$ & 2.98 & 36.6 (d) 3.08 \\
\hline 21 & $14.5(q)$ & $1.12(\mathrm{~d}, 7.0)$ & $14.3(\mathrm{q}) 1.19(\mathrm{~d}, 6.5)$ \\
\hline 22 & $112.7(\mathrm{~s})$ & & $113.4(\mathrm{~s})$ \\
\hline 23 & $71.4(\mathrm{~d})$ & $3.90(\mathrm{~d}, 8.6)$ & 73.8 (d) $3.88(\mathrm{~d}, 8.7)$ \\
\hline 24 & 87.7 (d) & $3.96(\mathrm{dd}, 9.2,8.6)$ & 76.1 (d) 3.98 (dd, 9.5, 8.7) \\
\hline 25 & $38.0(\mathrm{~d})$ & 2.08 & 39.3 (d) 2.06 \\
\hline 26 & $64.2(\mathrm{t})$ & $3.56(\mathrm{dd}, 6.1,8.6)$ & $64.6(\mathrm{t}) 3.66(\mathrm{dd}, 11.6,8.6)$ \\
\hline 27 & $13.2(q)$ & $1.20(\mathrm{~d}, 6.4)$ & $13.8(\mathrm{q}) 1.08(\mathrm{~d}, 6.7)$ \\
\hline 6-O-Glc-1 & $106.0(\mathrm{~d})$ & $4.91(\mathrm{~d}, 7.8)$ & \\
\hline 2 & $75.9(\mathrm{~d})$ & 4.04 & \\
\hline 3 & 78.7 (d) & 4.24 & \\
\hline 4 & $72.0(\mathrm{~d})$ & 4.22 & \\
\hline 5 & $78.2(d)$ & 3.87 & \\
\hline 6 & $63.0(\mathrm{t})$ & $4.43,4.33$ & \\
\hline 4-O-Glc-1 & $105.4(d)$ & $4.94(\mathrm{~d}, 7.9 \mathrm{~Hz})$ & \\
\hline 2 & $75.4(d)$ & 4.04 & \\
\hline 3 & 78.5 (d) & 4.25 & \\
\hline 4 & 71.7 (d) & 4.18 & \\
\hline 5 & 78.4 (d) & 3.96 & \\
\hline 6 & $62.6(\mathrm{t})$ & $4.49,4.27$ & \\
\hline
\end{tabular}

Spectra were measured at $125 \mathrm{MHz}$ for ${ }^{13} \mathrm{C}$ and $500 \mathrm{MHz}$ for ${ }^{1} \mathrm{H}$ in pyridine- $d_{5}$

showed four characteristic methyl signals at $\delta 1.01(\mathrm{~s}), 0.75$ (s), $1.15(\mathrm{~d}, J=7.1 \mathrm{~Hz})$ and $1.19(\mathrm{~d}, J=6.5 \mathrm{~Hz})$, and only one anomeric proton signal at $\delta 4.88(\mathrm{~d}, J=7.8 \mathrm{~Hz}$ ). Acid hydrolysis of $\mathbf{2}$ gave D-glucose as sugar residue by GC analysis. Comparison the ${ }^{13} \mathrm{C}-\mathrm{NMR}$ data of the aglycone moiety with those of tigogenin ${ }^{2)}$ and $\mathbf{1}$ implied that $\mathbf{2}$ differed from tigogenin in terms of the substitutions of F ring, which were identical to those of $\mathbf{1}$, based on the detailed analysis of the ${ }^{1} \mathrm{H}-{ }^{1} \mathrm{H}$ COSY spectrum and HMQC spectrum of the proton 
and carbon signals arising from the F-ring part. Thus, the aglycone moiety of $\mathbf{2}$ was suggested to have three hydroxyl groups at C-3, C-23 and C-24 of a spirostan skeleton. In the HMBC spectrum, the methyl doublet signal at $\delta 1.19\left(\mathrm{H}_{3}-27\right)$ was correlated with the carbon signals at $\delta 37.9(\mathrm{C}-25), 64.1$ $(\mathrm{C}-26)$ and $87.9(\mathrm{C}-24)$, and the proton signals at $\delta 3.01(\mathrm{H}-$ $20)$ and $3.96(\mathrm{H}-24)$ were correlated respectively with the carbon signal at $\delta 71.4(\mathrm{C}-23)$. These observations confirmed the structure of the F-ring part, and its connection with the Ering part through the $\mathrm{C}-22$ acetal carbon. The configurations of $\mathbf{2}$ were determined to be the same as $\mathbf{1}$ as $3 \beta, 22 S, 23 S$, $24 R$ and $25 S$, according to their similar features of the ${ }^{13} \mathrm{C}$ NMR chemical shifts, proton coupling constants, and ROESY correlations. Moreover, an HMBC correlation of the anomeric proton signal at $\delta 4.88$ with $\delta 87.9(\mathrm{C}-24)$ revealed the $\beta$-D-glucopyranosyl moiety attached at C-24 in 2 . Therefore, 2 was assigned as $(22 S, 23 S, 24 R, 25 S)-5 \alpha$-spirostane$3 \beta, 23,24$-triol $24-O-\beta$-D-glucopyranoside, and named agamenoside I.

Compound 3 was determined to be $\mathrm{C}_{33} \mathrm{H}_{54} \mathrm{O}_{10}$ by HRFAB-MS $\left(m / z \quad 609.3590[\mathrm{M}-\mathrm{H}]^{-}\right)$and ${ }^{13} \mathrm{C}-\mathrm{NMR}$ spectroscopy. The negative-ion FAB-MS also showed a fragment ion peak at $m / z 447[\mathrm{M}-\mathrm{H}-162]^{-}$. The ${ }^{1} \mathrm{H}-\mathrm{NMR}$ spectrum exhibited four characteristic methyl proton signals at $\delta 0.77$ (s), $0.92(\mathrm{~s}), 0.80(\mathrm{~d}, J=7.3 \mathrm{~Hz})$ and $1.25(\mathrm{~d}, J=6.8 \mathrm{~Hz})$, as well as an anomeric proton signal at $\delta 5.29(\mathrm{~d}, J=8.0 \mathrm{~Hz})$. Acid hydrolysis of $\mathbf{3}$ yielded D-glucose determined by GC analysis. The $J$ value $(>7 \mathrm{~Hz})$ of the anomer proton as well as a set of carbon signals at $\delta 100.7,74.7,78.8,71.6,78.9$ and 62.6 indicated the sugar moiety to be a $\beta$-D-glucopyranose.

In the ${ }^{13} \mathrm{C}$-NMR spectrum of $\mathbf{3}$, the characteristic acetal carbon resonating at $\delta 109.1(\mathrm{C}-22)$ was assigned to be a spiroacetal carbon with two oxygens attached. Comparing the ${ }^{13} \mathrm{C}-\mathrm{NMR}$ data of aglycone moiety with those of tigogenin, ${ }^{2)}$ revealed that the partial structure rings $\mathrm{A}-\mathrm{E}(\mathrm{C}-1$ to $\mathrm{C}-21$ ) of $\mathbf{3}$ was similar to that of tigogenin. Significant differences were the carbon chemical shifts of F-ring. All the proton and carbon signals arising from $\mathrm{C}_{23}-\mathrm{C}_{24}-\mathrm{C}_{25}\left(\mathrm{C}_{27}\right)-\mathrm{C}_{26}$ of the F-ring part was identified by detailed analysis of the ${ }^{1} \mathrm{H}-{ }^{1} \mathrm{H}$ COSY spectrum followed by HMQC spectrum, in which ${ }^{1} \mathrm{H}-{ }^{1} \mathrm{H}$ correlations were observed for $\delta 4.58(\mathrm{H}-23)$ with $\delta 1.59$ and $2.55\left(\mathrm{H}_{2}-24\right)$, and for $\delta 2.44(\mathrm{H}-25)$ with $\mathrm{H}_{2}-$ $24, \delta 5.47(\mathrm{H}-26)$ and $\delta 0.80\left(\mathrm{H}_{3}-27\right)$. In the HMBC spectrum, correlations of $\delta 5.47(\mathrm{H}-26)$ with $\delta 85.2(\mathrm{C}-23)$ and 100.7 (C-1' ${ }^{\prime}$ of Glc) revealed that 3 was a 23,26 -epoxide and the glycosylated position at C-26. In addition, a proton signal at $\delta 5.93$ that was not correlated with any carbon signals in the HMQC spectrum was observed to correlate with carbon signals at $\delta 39.3(\mathrm{C}-20)$ and $109.1(\mathrm{C}-22)$ in the HMBC

Table 2. ${ }^{1} \mathrm{H}$ - and ${ }^{13} \mathrm{C}-\mathrm{NMR}$ Data of Compounds $\mathbf{2}-\mathbf{4}$

\begin{tabular}{|c|c|c|c|c|c|c|}
\hline \multirow{2}{*}{ No. } & \multicolumn{2}{|r|}{2} & \multicolumn{2}{|r|}{3} & \multicolumn{2}{|r|}{4} \\
\hline & $\delta_{\mathrm{C}}$ & $\delta_{\mathrm{H}}$ & $\delta_{\mathrm{C}}$ & $\delta_{\mathrm{H}}$ & $\delta_{\mathrm{C}}$ & $\delta_{\mathrm{H}}$ \\
\hline 1 & $37.5(\mathrm{t})$ & $0.92(\alpha), 1.64(\beta)$ & $37.6(t)$ & $0.94(\alpha), 1.64(\beta)$ & $37.6(\mathrm{t})$ & $0.94(\alpha), 2.29(\beta)$ \\
\hline 2 & $32.1(\mathrm{t})$ & $2.04(\alpha), 1.55(\beta)$ & $32.5(\mathrm{t})$ & $2.04(\alpha), 1.51(\beta)$ & $32.0(\mathrm{t})$ & $2.04(\alpha), 1.61(\beta)$ \\
\hline 3 & $70.6(d)$ & 3.83 & 70.7 (d) & 3.84 & 70.7 (d) & 3.86 \\
\hline 4 & $39.3(\mathrm{t})$ & $1.76(\alpha), 1.52(\beta)$ & $39.3(\mathrm{t})$ & $1.76(\alpha), 1.54(\beta)$ & $39.3(\mathrm{t})$ & $1.80(\alpha), 1.58(\beta)$ \\
\hline 5 & $45.6(\mathrm{~d})$ & 1.09 & $45.3(\mathrm{~d})$ & 1.08 & $45.3(\mathrm{~d})$ & 1.07 \\
\hline 6 & $29.1(\mathrm{t})$ & 1.19 & $29.1(\mathrm{t})$ & 1.20 & $29.3(\mathrm{t})$ & 1.23 \\
\hline 7 & $32.5(\mathrm{t})$ & $0.79(\alpha), 1.64(\beta)$ & $32.5(\mathrm{t})$ & $0.74(\alpha), 1.60(\beta)$ & $32.5(\mathrm{t})$ & $1.72(\alpha), 0.80(\beta)$ \\
\hline 8 & 35.3 (d) & 1.43 & 35.5 (d) & 1.48 & $35.6(d)$ & 1.50 \\
\hline 9 & $54.6(\mathrm{~d})$ & 0.56 & 54.7 (d) & 0.57 & $54.9(\mathrm{~d})$ & 0.60 \\
\hline 10 & $35.9(\mathrm{~s})$ & & $35.9(\mathrm{~s})$ & & $35.9(\mathrm{~s})$ & \\
\hline 11 & $21.4(\mathrm{t})$ & $1.21(\alpha), 1.46(\beta)$ & $21.4(\mathrm{t})$ & $1.24(\alpha), 1.47(\beta)$ & $21.5(\mathrm{t})$ & $1.30(\alpha), 1.47(\beta)$ \\
\hline 12 & $40.7(t)$ & $1.11(\alpha), 1.84(\beta)$ & $40.2(\mathrm{t})$ & $1.10(\alpha), 1.76(\beta)$ & $40.8(\mathrm{t})$ & $1.13(\alpha), 2.04(\beta)$ \\
\hline 13 & $41.4(\mathrm{~s})$ & & $41.3(\mathrm{~s})$ & & $43.1(\mathrm{~s})$ & \\
\hline 14 & $56.6(\mathrm{~d})$ & 1.10 & 56.7 (d) & 1.04 & $54.9(\mathrm{~d})$ & 0.91 \\
\hline 15 & $32.5(\mathrm{t})$ & $2.04(\alpha), 1.70(\beta)$ & $32.2(\mathrm{t})$ & $1.97(\alpha), 1.67(\beta)$ & $37.2(\mathrm{t})$ & $2.30(\alpha), 1.61(\beta)$ \\
\hline 16 & $82.0(\mathrm{~d})$ & 4.62 (q-like, 7.0$)$ & $81.5(\mathrm{~d})$ & 4.90 (q-like, 7.4$)$ & $71.6(d)$ & $4.77(\mathrm{ddd}, 7.7,4.2,7.3)$ \\
\hline 17 & $62.0(\mathrm{~d})$ & $1.85(\mathrm{dd}, 6.5,7.0)$ & $64.9(\mathrm{~d})$ & $1.87(\mathrm{dd}, 5.8,7.4)$ & $58.3(\mathrm{~d})$ & 1.69 \\
\hline 18 & $17.0(q)$ & $1.01(\mathrm{~s})$ & $16.6(q)$ & $0.93(\mathrm{~s})$ & $17.7(q)$ & $1.15(\mathrm{~s})$ \\
\hline 19 & $12.5(\mathrm{q})$ & $0.75(\mathrm{~s})$ & $12.6(q)$ & $0.78(\mathrm{~s})$ & $12.6(q)$ & $0.83(\mathrm{~s})$ \\
\hline 20 & 36.4 (d) & 3.01 & 39.3 (d) & $2.15(\mathrm{dd}, 5.2,6.4)$ & 36.1 (d) & 2.59 \\
\hline 21 & $14.5(\mathrm{q})$ & $1.15(\mathrm{~d}, 7.1)$ & $16.6(q)$ & $1.25(\mathrm{~d}, 5.2)$ & $15.3(q)$ & $1.20(\mathrm{~d}, 6.4)$ \\
\hline 22 & $112.7(\mathrm{~s})$ & & $109.1(\mathrm{~s})$ & $5.93(\mathrm{~s})$ & $75.6(d)$ & $4.23(\mathrm{dd}, 6.4,6.0)$ \\
\hline 23 & $71.4(\mathrm{~d})$ & $3.84(\mathrm{~d}, 9.0)$ & $85.2(\mathrm{~d})$ & $4.58(\mathrm{dd}, 8.6,6.4)$ & $32.5(\mathrm{t})$ & $1.33,2.05$ \\
\hline 24 & 87.9 (d) & $3.96(\mathrm{dd}, 9.5,9.0)$ & $32.5(\mathrm{t})$ & $2.55(\alpha), 1.59(\beta)$ & $31.6(\mathrm{t})$ & 1.86 \\
\hline 25 & 37.9 (d) & 2.05 & $40.3(\mathrm{~d})$ & 2.44 & $37.1(\mathrm{~d})$ & 1.92 \\
\hline 26 & $64.1(\mathrm{t})$ & $3.60(\mathrm{dd}, 8.9,5.9)$ & $107.3(d)$ & 5.47 (br s, 1.9) & $67.7(\mathrm{t})$ & $\begin{array}{l}3.70(\mathrm{dd}, 11.0,3.5) \\
3.80(\mathrm{dd}, 11.0,5.7)\end{array}$ \\
\hline 27 & $13.2(\mathrm{q})$ & $1.19(\mathrm{~d}, 6.5)$ & $16.8(q)$ & $0.80(\mathrm{~d}, 7.4)$ & $17.7(q)$ & $1.11(\mathrm{~d}, 6.4)$ \\
\hline Glc-1 & $105.4(\mathrm{~d})$ & $4.88(\mathrm{~d}, 7.8)$ & $100.7(d)$ & $5.29(\mathrm{~d}, 8.0)$ & & \\
\hline 2 & $75.4(\mathrm{~d})$ & 4.04 & $74.7(\mathrm{~d})$ & 4.02 & & \\
\hline 3 & $78.3(\mathrm{~d})$ & 3.90 & $78.8(\mathrm{~d})$ & 4.16 & & \\
\hline 4 & 71.4 (d) & 4.21 & $71.6(d)$ & 4.15 & & \\
\hline 5 & 78.5 (d) & 4.18 & 78.9 (d) & 3.84 & & \\
\hline 6 & $62.5(\mathrm{t})$ & $4.47,4.30$ & $62.6(\mathrm{t})$ & $4.47,4.32$ & & \\
\hline
\end{tabular}


spectrum. This proton signal ( $\delta$ 5.93) was also showed correlations with H-16, H-24 $\alpha$ and H-Glc-1 in the ROESY spectrum. When added a drop of $\mathrm{D}_{2} \mathrm{O}$ into the NMR test tube of 3 , this proton signal at $\delta 5.93$ was disappeared in the ${ }^{1} \mathrm{H}$ NMR spectrum. These observations suggested the proton signal ( $\delta 5.93)$ attributable to the proton of hydroxyl group at C-22.

In the ROESY spectrum, correlations from $\delta 3.84(\mathrm{H}-3)$ to $\delta 0.94(\mathrm{H}-1 \alpha), 1.08(\mathrm{H}-5 \alpha), 1.76(\mathrm{H}-14 \alpha)$, and $\delta 2.04(\mathrm{H}-$ $2 \mathrm{a})$, assigned the $\beta$-orientation of $3-\mathrm{OH}$. The ROESY correlations of $\delta 4.90$ (H-16) with $\delta 1.04$ (H-14), 1.97 (H-15 $\alpha$, $1.87(\mathrm{H}-17)$, and $5.93(\mathrm{H}-\mathrm{O}-22)$, indicated the $\alpha$-orientation of these protons and the $22 S$ configuration. The ${ }^{1} \mathrm{H}$ - and ${ }^{13} \mathrm{C}$ NMR data for the rings $\mathrm{C}-\mathrm{F}$ of $\mathbf{3}$ were identical with those of anguivioside $\mathrm{XI},{ }^{22)}$ suggesting that the configurations at $\mathrm{C}$ 23 and $\mathrm{C}-25$ were the same as those of anguivioside XI. The ROESY correlations of $\delta 5.93(\mathrm{H}-\mathrm{O}-22)$ with $\delta 2.55(\mathrm{H}-$ $24 \alpha$ ) and 5.29 (H-Glc-1), and of $\delta 4.58(\mathrm{H}-23)$ with $\delta 2.15$ $(\mathrm{H}-20), 1.59(\mathrm{H}-24 \beta), 0.93\left(\mathrm{H}_{3}-18\right), 5.47(\mathrm{H}-26)$ and 0.80 $\left(\mathrm{H}_{3}-27\right)$, were also consistent with the $20 \mathrm{~S}, 23 \mathrm{~S}, 25 \mathrm{R}$ and $26 S$ configurations. Therefore, the structure of agamenoside $\mathrm{J}$ (3) was elucidated as $(22 S, 23 S, 25 R, 26 S)$-23,26-epoxy-5 $\alpha$ furostane-3 $\beta, 22,26$-triol $26-O$ - $\beta$-D-glucopyranoside.

The molecular formula of compound $\mathbf{4}$ was determined as $\mathrm{C}_{27} \mathrm{H}_{48} \mathrm{O}_{4}$ on the basis of HR-EI-MS $\left(\mathrm{m} / \mathrm{z} 436.3504[\mathrm{M}]^{-}\right)$ and ${ }^{13} \mathrm{C}$ DEPT spectrum. The ${ }^{1} \mathrm{H}-\mathrm{NMR}$ spectrum showed four characteristic methyl proton signals at $\delta 1.15$ (s), 0.83 (s), $1.20(\mathrm{~d}, J=6.4 \mathrm{~Hz})$ and $1.11(\mathrm{~d}, J=6.4 \mathrm{~Hz})$. However, there was no quaternary carbon signal around $\delta 110$ characteristic of the spirostanol skeleton in the ${ }^{13} \mathrm{C}-\mathrm{NMR}$ spectrum, nevertheless a set of side chain signals. These observations suggested the presence of a cholestan skeleton.

All of the ${ }^{1} \mathrm{H}$ - and ${ }^{13} \mathrm{C}-\mathrm{NMR}$ signals of 4 were assigned with the aid of the ${ }^{1} \mathrm{H}-{ }^{1} \mathrm{H}$ COSY, HMQC, HMBC and NOESY spectra as shown in Table 2, and they indicated 4 to be a cholestan steroid with four hydroxyl groups attached at C-3, C-16, C-22 and C-26, respectively. The similarity ${ }^{1} \mathrm{H}-$ and ${ }^{13} \mathrm{C}-\mathrm{NMR}$ data of rings $\mathrm{A}-\mathrm{C}$ with tigogenin ${ }^{2)}$ and partial structure of $\mathrm{C}-12$ to $\mathrm{C}-27$ with $(22 S, 25 S)-16 \beta, 22,26$-trihydrocholest-4-en-3-one, ${ }^{23)}$ assumed that the hydroxyl group at $\mathrm{C}-3$ was $\beta$-orientation and the configurations of $\mathrm{C}-16, \mathrm{C}-22$ and $\mathrm{C}-25$ were the same as those of $(22 S, 25 S)-16 \beta, 22,26$-trihydrocholest-4-en-3-one. In the ROESY spectrum of 4, H-3 $(\delta$ 3.86) was correlated with $\mathrm{H}-1 \alpha(\delta 0.94), \mathrm{H}-2 \alpha(\delta 2.04)$, $\mathrm{H}-4 \alpha(\delta 1.80)$ and $\mathrm{H}-5(\delta 1.07)$ that confirmed the $\beta$-orientation of the hydroxyl group at C-3 and the $\alpha$-orientation of $\mathrm{H}$ 5. The nuclear Overhauser effect (NOE) correlations of H-16 $(\delta$ 4.77) with H-17 ( $\delta$ 1.69), H-15 $\alpha(\delta 2.30)$ and H-22 $(\delta$ $4.23)$ indicated the $\alpha$-orientation of $\mathrm{H}-17$ and $\beta$-orientation of the hydroxyl group at $\mathrm{C}-16$. Moreover, other correlations of $\delta 2.59(\mathrm{H}-20)$ with $\delta 1.15(\mathrm{H}-18)$ and $\delta 4.23(\mathrm{H}-22)$, and $\delta 4.23(\mathrm{H}-22)$ with $\delta 4.77(\mathrm{H}-16), \delta 2.59(\mathrm{H}-20), \delta 1.33(\mathrm{H}-$ $23)$ and $\delta 1.86(\mathrm{H}-24)$ were also observed in the ROESY spectrum. Therefore, the structure of 4 can be represented as (22S,25S)-5 $\alpha$-cholestane-3 $\beta, 16 \beta, 22,26$-tetrol, and designated as agavegenin $\mathrm{D}$.

The spirostan sapogenins reported previously from the genus of Agave existed two epimers at C-5 and C-25, and some of which had hydroxyl groups attached at C-6, C-12, C-23 and C-27 positions of the aglycone..$^{7,9-11)}$ However, all of the spirostan steroids we have obtained from the waste residue were $5 \alpha-\mathrm{H}$ and $25 S$ skeleton, and some compounds had hydroxyl groups at C-6, C-11, C-24 and C-27 of the aglycone. It is noticed that agamenoside $\mathrm{J}$ (3) was a novel spirostane glycoside with a free hydroxyl group attached at C-22 and 23,26-epoxyfurost skeleton. It might be formed during the fermented process of $A$. americana leaves.

\section{Experimental}

Optical rotations were measured with HORIBA SEPA-300 high-sensitive polarimeter. IR (KBr) spectra were measured on Bio-Rad FTS-135 spectrophotometer. NMR spectra were recorded in pyridine- $d_{5}$, on a Bruker DRX-500 instrument at $25^{\circ} \mathrm{C}$, using TMS as an internal standard. The negative ion and high-resolution FAB mass spectra were recorded on a VG AutoSpec3000 mass spectrometer using glycerol as matrix. GC was performed on Fisons MD800 GC/MS. Silica gel (Qingdao Haiyang Chemical Co.), RP8 (Merck) were used for column chromatography; D-glucose (Merck) was used as standard reagent for GC. Precoated silica gel plates (Qingdao Haiyang Chemical Co.) were used for TLC. Detection was done by spraying the plates with $10 \% \mathrm{H}_{2} \mathrm{SO}_{4}$, followed by heating.

Material The dried waste residues of fibre separation from A. americana L. leaves were collected from a factory in Ruili County of Yunnan Province at January 2000.

Extraction and Isolation The dried waste residues $(6.5 \mathrm{~kg})$ of fibre separation from $A$. americana L. leaves were extracted with hot $\mathrm{MeOH}$ for three times. After removal of the $\mathrm{MeOH}$ under reduced pressure, the concentrated extract was partitioned between $n$ - $\mathrm{BuOH}$ and $\mathrm{H}_{2} \mathrm{O}$. The $n$ - $\mathrm{BuOH}$ layer was concentrated and applied to a silica gel column, eluting with $\mathrm{CHCl}_{3}$ $\mathrm{MeOH}-\mathrm{H}_{2} \mathrm{O}(7: 2.5: 0.4)$, to give three fractions (I-III). Fraction I was repeatedly chromatographed on silica gel with $\mathrm{CHCl}_{3}-\mathrm{MeOH}-\mathrm{H}_{2} \mathrm{O}$ and RP-8 with $\mathrm{MeOH}-\mathrm{H}_{2} \mathrm{O}$ to give (25R)-5 $\alpha$-spirostane- $3 \beta, 6 \alpha$-diol (chlorogenin) (889 mg), chlorogenin 6- $O$ - $\beta$-D-glucopyranoside (560 mg), 9(11)-dehydroxyhecogenin $(136 \mathrm{mg})$, manogenin $(22 \mathrm{mg})$, daucosterol $(143 \mathrm{mg}), 7 \alpha$-hydroxysitosterol 3- $O$ - $\beta$-D-glucopyranoside (17 mg), 2 (24 mg), 3 (15 mg), and $4(52 \mathrm{mg})$. Fraction III was subjected to repeated column chromatographies of normal and reverse silica gel to afford $1(83 \mathrm{mg})$.

Agamenoside $\mathbf{H}$ (1) A white amorphous powder, $[\alpha]_{\mathrm{D}}^{21}-42.1^{\circ}$ $\left(c=0.011\right.$, pyridine). IR $(\mathrm{KBr}) \mathrm{cm}^{-1}: 3439(\mathrm{OH}), 2925(\mathrm{CH}), 1457,1380$, $1165,1036,895,868 .{ }^{1} \mathrm{H}-$ and ${ }^{13} \mathrm{C}-\mathrm{NMR}\left(\mathrm{C}_{5} \mathrm{D}_{5} \mathrm{~N}\right)$ : Table 1. FAB-MS (negative mode) $m / z: 787[\mathrm{M}-\mathrm{H}]^{-}$. HR-FAB-MS $m / z$ : $787.4177[\mathrm{M}-\mathrm{H}]^{-}$(calcd for $[\mathrm{M}-\mathrm{H}]^{-}, \mathrm{C}_{39} \mathrm{H}_{63} \mathrm{O}_{16}: 787.4116$ ).

Acid Hydrolysis of 1 Compound 1 (24 mg) was refluxed with $1 \mathrm{~m}$ $\mathrm{HCl}$-dioxane $(1: 1, \mathrm{v} / \mathrm{v}, 4 \mathrm{ml})$ on water bath for $6 \mathrm{~h}$. The reaction mixture was evaporated to dryness. The dried reaction mixture was extracted by $\mathrm{CHCl}_{3}$ four times. The $\mathrm{CHCl}_{3}$ extract was concentrated and chromatographed on silica gel to give agavegenin C (1a) ( $9 \mathrm{mg})$ : white powder, IR (KBr) $\mathrm{cm}^{-1}: 3559$, 3435, 2941, 2920, 2885, 2862, 1452, 1382, 1182, 1106, 1086, 1048, 1012, 989, 960, 937, 873. ${ }^{1} \mathrm{H}-$ and ${ }^{13} \mathrm{C}-\mathrm{NMR}\left(\mathrm{C}_{5} \mathrm{D}_{5} \mathrm{~N}\right)$ : Table 1. EI-MS $m / z$ : 464, 445, 405, 376, 363, 345, 327, 318, 303, 289, 271, 253, 159, 147, 121, 107, 95. HR-EI-MS m/z: 464.3114 [M] $^{-}$(calcd for $[\mathrm{M}]^{-}, \mathrm{C}_{27} \mathrm{H}_{44} \mathrm{O}_{6}$ : 464.3114). The dried sugar residues was diluted in $5 \mathrm{ml}$ pyridine without water and treated with $0.5 \mathrm{ml}$ trimethyl-chlorsilan (TMCS, Fluka) at room temperature for $30 \mathrm{~min}$. The reaction mixture was evaporated to dryness under reduced pressure. The mixture of trimethylsilylated derivatives of the monosaccharides was diluted in $0.5 \mathrm{ml}\left(\mathrm{CH}_{3}\right)_{2} \mathrm{O}$ without water and then analyzed by GC. GC condition: AC-5 capillary column $(30 \mathrm{~m} \times$ $\phi 0.25 \mathrm{~mm})$, detector: FID $\left(270^{\circ} \mathrm{C}\right)$, column temperature: $180-260^{\circ} \mathrm{C}$, rate: $5^{\circ} \mathrm{C} / \mathrm{min}, t_{\mathrm{R}}$ (second): 692 (D-glucose).

Agamenoside I (2) A white amorphous powder, $[\alpha]_{\mathrm{D}}^{14}-39.9^{\circ}$ $\left(c=0.041\right.$, pyridine). IR (KBr) $\mathrm{cm}^{-1}: 3432,2927,1457,1713,1641,1452$, $1380,1166,963,941,875,796 .{ }^{1} \mathrm{H}-$ and ${ }^{13} \mathrm{C}-\mathrm{NMR}\left(\mathrm{C}_{5} \mathrm{D}_{5} \mathrm{~N}\right)$ : Table 2. FABMS (negative mode) $\mathrm{m} / z: 609[\mathrm{M}-\mathrm{H}]^{-}, 447[\mathrm{M}-\mathrm{H}-\mathrm{Glc}]^{-}$. HR-FAB-MS $m / z: 609.3676[\mathrm{M}-\mathrm{H}]^{-}$(calcd for $\left.[\mathrm{M}-\mathrm{H}]^{-}, \mathrm{C}_{33} \mathrm{H}_{53} \mathrm{O}_{10}: 609.3639\right)$.

Acid Hydrolysis of 2 Compound 2 (2 mg) was subjected to acid hydrolysis as described for $\mathbf{1}$ to give D-glucose as sugar moiety by GC analysis.

Agamenoside $\mathbf{J}$ (3) A white amorphous powder, $[\alpha]_{\mathrm{D}}^{21}-37.1^{\circ}$ ( $c=0.018$, pyridine). ${ }^{1} \mathrm{H}$ - and ${ }^{13} \mathrm{C}-\mathrm{NMR}\left(\mathrm{C}_{5} \mathrm{D}_{5} \mathrm{~N}\right)$ : Table 2 . FAB-MS (negative mode) $m / z: 609[\mathrm{M}-\mathrm{H}]^{-}, 447[\mathrm{M}-\mathrm{H}-\mathrm{Glc}]^{-}$. HR-FAB-MS $m / z$ : $609.3590[\mathrm{M}-\mathrm{H}]^{-}$(calcd for $[\mathrm{M}-\mathrm{H}]^{-}, \mathrm{C}_{33} \mathrm{H}_{53} \mathrm{O}_{10}: 609.3639$ ).

Acid Hydrolysis of 3 Compound $3(2 \mathrm{mg})$ was subjected to acid hydrolysis as described for $\mathbf{1}$ to give D-glucose as sugar moiety by GC analysis.

Agavegenin D (4) A white amorphous powder, $[\alpha]_{\mathrm{D}}^{21}-13.3^{\circ}(c=0.017$, pyridine). ${ }^{1} \mathrm{H}$ - and ${ }^{13} \mathrm{C}-\mathrm{NMR}$ data see Table 2. EI-MS $m / z: 435[\mathrm{M}-\mathrm{H}]^{-}$, 416, 400, 386, 317, 318, 302, 287, 273 (base peak), 255, 231, 215, 199, 187, 
161, 147, 121, 109, 99, 81. HR-EI-MS $m / z: 436.3504$ [M] $^{-}$(calcd for [M] ${ }^{-}$, $\left.\mathrm{C}_{27} \mathrm{H}_{48} \mathrm{O}_{4}: 436.3553\right)$.

Acknowledgments This work was financially supported by the National Natural Science Foundation of China (NSFC) (39969005). The authors are grateful to members of the analytical group of State Key Laboratory of Phytochemistry and Plant Resources in West China, Kunming Institute of Botany, for measurements of all spectra. We are also grateful to Professor Xingcong Li (University of Mississippi) for his help.

\section{References and Notes}

1) Jiangsu New Medical College. "Zhong-yao-da-ci-dian," Shanghai People's Publisher, Shanghai, 1977, p. 1414.

2) Ding Y., Chen Y.-Y., Wang D.-Z., Yang C.-R., Phytochemistry, 28, 2787-2791 (1989).

3) Jiangsu New Medical College. "Xin-Hua-Ben-Cao-Guang-Yao," Shanghai Technology Publisher, Shanghai, 1988, p. 500.

4) Ding Y., Tian R.-H., Yang C.-R., Chem. Pharm. Bull., 41, 557-560 (1993).

5) Alessandra A. T., Mario D. L. M., Vincenza M. D., Guiseppe P. P., Planta Med., 63, 199-202 (1997).

6) Wilkomirski B., Bobeyko V. A., Kintya P. K., Phytochemistry, 14, 2657-2659 (1975).

7) Yokosuka A., Mimaki Y., Kuroda M., Sashida Y., Planta Med., 66, 393-396 (2000).

8) Kintya P. K., Bobeiko V. A., Prir. Soedin., 1979, 102-104 (1979).

9) Zhou J., Wu D.-G., Hang W.-G., Acta Pharmaceutica Sinica, 12,
392-397 (1965).

10) Chen Y.-Y., Cong P.-Z., Hang L., Acta Chimica Sinica, 33, 149-155 (1975).

11) Chen Y.-Y., Hang L., Acta Bot. Sinica, 18, 156-162 (1976).

12) Jin J.-M., Liu X.-K., Teng R.-W., Yang C.-R., Chinese Chem. Lett., 13, $629-632(2002)$

13) Jin J.-M., Liu X.-K., Yang C.-R., J. Asian Nat. Prod. Res., 5, 95-103 (2003).

14) Jin J.-M., Yang C.-R., Chinese Chem. Lett., 14, 491-494 (2003).

15) Mimaki Y., Sashida Y., Kawashima K., Phytochemistry, 30, 37213727 (1991).

16) Mimaki Y., Nakamura O., Sashida Y., Nikaido T., Ohmoto T., Phytochemistry, 38, 1279-1286 (1995).

17) Zhang Y.-J., Yang C.-R., Acta Botanica Yunnanica, 16, 401-406 (1995).

18) Chaurasia N., Wichtl M., J. Nat. Prod., 50, 881-885 (1987).

19) Teng R.-W., Jin J.-M., Wang D.-Z., Yang C.-R., Chin. J. of Magn. Reson., 18, 291-297 (2001).

20) Ono M., Yanai Y., Ikeda T., Okawa M., Nohara T., Chem. Pharm. Bull., 51, 1328-1331 (2003).

21) Eddy C. R., Wall M. E., Scott M. K., Anal. Chem., 25, 266-271 (1953).

22) Honbu T., Ikeda T., Zhu X.-H., Yoshihara O., Okawa M., Nafady A. M., Nohara T., J. Nat. Prod., 65, 1918-1920 (2002).

23) Achenbach H., Hubner H., Reiter M., Phytochemsitry, 41, 907-917 (1996). 